\title{
Studi Komparasi Antivirus Pada Sistem Operasi Berbasis
}

\section{Smartphone}

\author{
John Reimon Batmetan, Christinne M. T. P. Subagyo, Mersy. E. L. Sumangkut, Yunitha R. Sumarandak \\ Pendidikan Teknologi Informasi dan Komunikasi Universitas Negeri Manado, Tondano, 95618
}

john.reimon@gmail.com, subagyochristinne@gmail.com, mersysumangkut@gmail.com, yunce23@gmail.com

\begin{abstract}
ABSTRAK
Perkembangan Anti-Virus berkembang dengan pesat. Ada yang berbayar dan ada pula yang gratis. Dengan semakin bertambahnya aplikasi Anti-Virus, para pengguna smartphone dihadapkan dengan beberapa pilihan aplikasi Anti-Virus. Tidak semua pengguna smartphone mengetahui cara kerja serta kelebihan dan kekurangan dari masing-masing AntiVirus. Tujuan dari penelitian ini adalah untuk mengetahui kekurangan dan kelebihan dari 360 Security dan CM Security. Manfaat dari pemelitian ini adalah memudahkan para pengguna smartphone dalam memilih aplikasi Anti-Virus yang tepat pada smartphonenya masing-masing. Penelitian ini akan menggunakan metode wawancara, observasi, analisis dan perancangan. Hasil dari penelitian ini adalah sebuah data yang dapat digunakan oleh pengguna smartphone sebagai referensi dan pembanding dari 360 Security dan CM Security.
\end{abstract}

Kata Kunci: Anti-virus, android, security

\section{PENDAHULUAN}

Saat ini pengguna Anti-Virus dalam menetapkan produk Anti-Virus yang digunakannya hanya berdasarkan pada info dari pengguna lain, apa yang sudah terinstall pada saat membeli smartphone dan beberapa Anti-Virus gratis yang tersedia di internet. Artinya, pengguna Anti-Virus memilih produk AntiVirus bukan karena pengetahuan mereka terhadap produk AntiVirus yang dipilihnya, tetapi karena faktorfaktor tersebut. Banyak situs di internet yang memperbandingkan berbagai AntiVirus, tetapi situs tersebut tidak berdiri sendiri melainkan disponsori oleh salah satu Anti-Virus yang dibandingkan, oleh karena itu hasil dari perbandingan tersebut tidak adil karena memenangkan produk Anti-Virus yang mensponsori situs tersebut. Karena banyaknya produk AntiVirus yang beredar di pasaran, serta penelitian ini berdiri sendiri karena perbandingan ini tidak disponsori oleh salah satu Anti-Virus yang diteliti.

\section{METODE}

Teknik sampling adalah sebuah metode atau cara yang dilakukan untuk menentukan jumlah dan anggota sampel. Setiap anggota tentu saja wakil dari populasi yang dipilih setelah dikelompokkan berdasarkan kesamaan karakter. Teknik sampling yang digunakan juga harus disesuaikan dengan tujuan dari penelitian. Penelitian ini memutuskan untuk memilih dua produk Anti-Virus berdasarkan hasil survey dari 32 responden secara acak (menggunakan random sampling metodologi). Random sampling dilakukan untuk memperluas cakupan lokasi maupun ragam tipe responden sebagai argumentasi. Populasi 
terdiri dari sekumpulan individu yang bersifat heterogen terbatas. Ada banyak variasi variabel yang melekat pada masing-masing individu. Perbedaan ini bisa disebabkan oleh faktor internal dan eksternal dari individu seperti halnya wilayah tempat tinggal, tingkat pendidikan, budaya atau gaya hidup dalam suatu daerah tertentu. Subjektifitas dari individuindividu yang memiliki sifat determinan yang berulang pada populasi akhirnya membentuk karakter dari populasi secara umum. Berdasarkan karakter ini, dapat disimpulkan bahwa pengambilan sampel dari populasi tidak bisa dilakukan begitu saja namun dibutuhkan suatu teknik agar sampel yang ditarik tetap representatif.

Hal yang perlu diperhatikan dalam pengambilan sampel atau sampling adalah seluruh variabel yang berkaitan dengan penelitian. Unsur-unsur khusus yang melekat pada pribadi tentu saja perlu diperhatikan karena individu dengan kemampuan khusus dalam sampel akan membawa bias data dan tentu saja mempengaruhi distribusi data yang ada. Kesesuaian karakteristik daerah, tingkatan, dan juga kecenderungan khusus juga perlu dipertimbangkan dalam memilih teknik sampling yang sesuai.

Menurut Kerlinger (2006:188), simple random sampling adalah metode penarikan dari sebuah populasi atau semesta dengan cara tertentu sehingga setiap anggota populasi atau semesta tadi memiliki peluang yang sama untuk terpilih atau terambil.

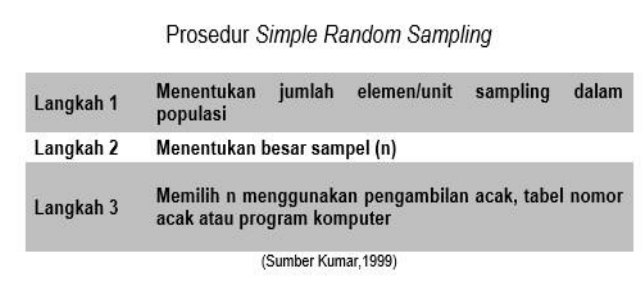

Menurut Sugiyono (2001:57) dinyatakan simple (sederhana) karena pengambilan sampel anggota populasi dilakukan secara acak tanpa memperhatikan strata yang ada dalam populasi itu. Margono (2004:126) menyatakan bahwa simple random sampling adalah teknik untuk mendapatkan sampel yang langsung dilakukan pada unit sampling. Cara demikian dilakukan bila anggota populasi dianggap homogen. Teknik ini dapat dipergunakan bilamana jumlah unit sampling di dalam suatu populasi tidak terlalu besar. Misal, populasi terdiri dari 500 orang mahasiswa program S1 (unit sampling). Untuk memperoleh sampel sebanyak 150 orang dari populasi tersebut, digunakan teknik ini, baik dengan cara Studi komparasi antivirus pada sistem operasi berbasis smartphone adalah salah satu cara untuk membandingkan satu produk dengan produk lainya. Penelitian ini dilakukan untuk mencari tahu bagaimana tanggapan masyarakat luas mengenai 2 produk yang kami bandingkan ini. Melihat hasil test, para responden lebih banyak menggunakan CM Security. CM Security adalah aplikasi pembersihan yang lengkap yang mengijinkan anda menjaga piranti Android selalu dalam keadaan sempurna, terima kasih pada pilihan optimasi yang berbeda yang ada di dalamnya yang akan membersihkan tempat penyimpanan sementara, menghapus tempat penyimpanan sementara, atau membersihkan jejak pemakaian dalam smartphone. undian, ordinal, maupun tabel bilangan random. Teknik ini dapat digambarkan di bawah ini.

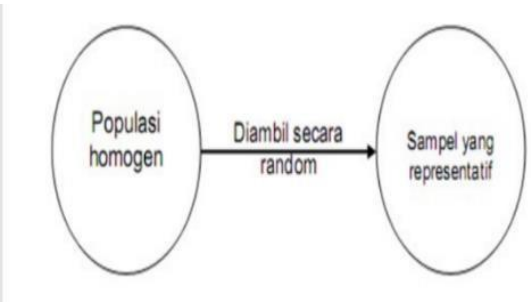

HASIL DAN PEMBAHASAN 


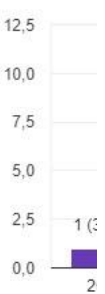

16
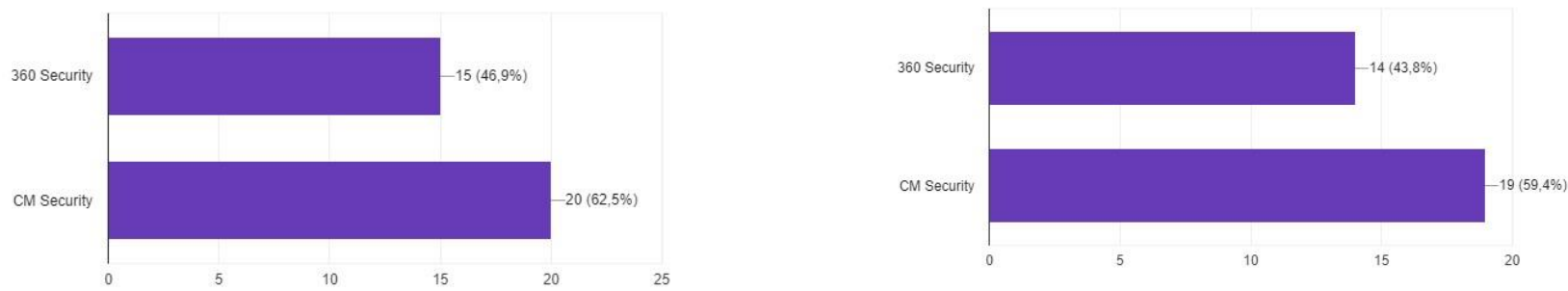

Saya mengetahui Anti-Virus 360 Security dan CM Security 32 tanggapan

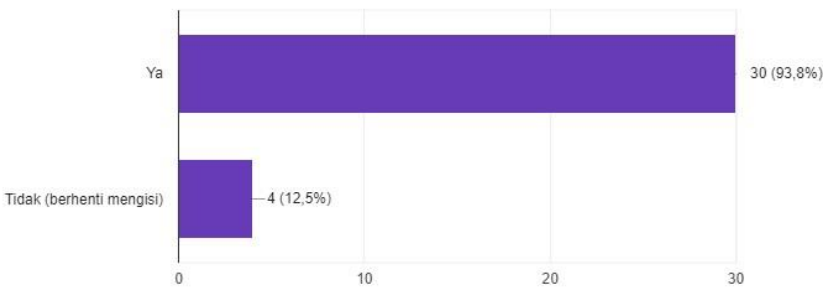

Saya mengingat salah satu iklan Anti-Virus di Internet 32 tanggapar

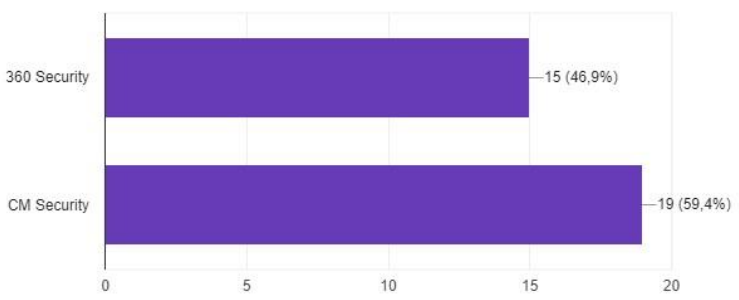

Anti-Virus yang lebih berkualitas 32 tanggapan

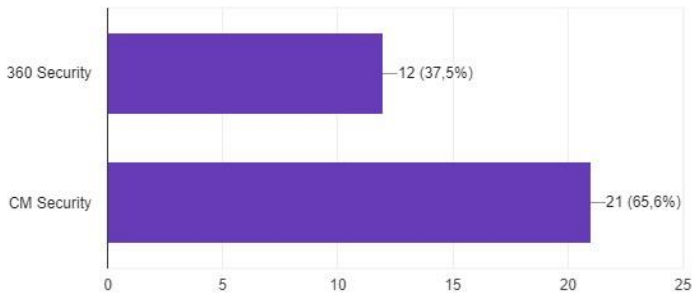

Anti-Virus yang lebih cocok untuk berbagai kalangan/smartphone 32 tanggapan

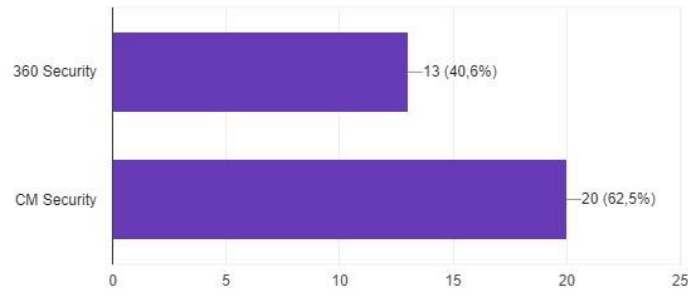

Anti-Virus yang diproduksi oleh perusahaan yang kredibilitasnya lebih tinggi (terpercaya)

32 tanggapar

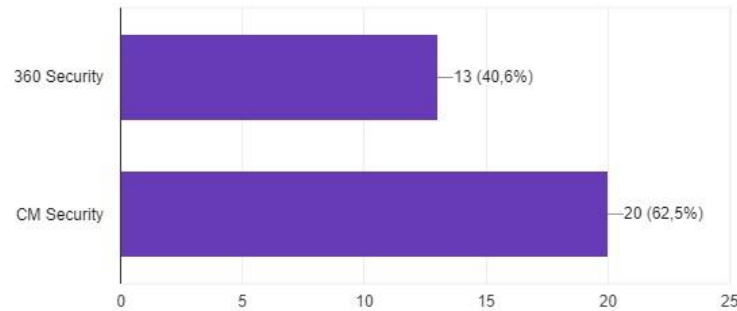


Tabel 1. Hasil Presentase Kesadaran Merek (Brand Awareness)

\begin{tabular}{llcc}
\hline No. & \multicolumn{1}{c}{$\begin{array}{c}\text { Pernyataan / } \\
\text { Pertanyaan }\end{array}$} & \multicolumn{2}{c}{ Presentase } \\
\cline { 3 - 4 } & & $\begin{array}{c}\text { CM } \\
\text { Securiry }\end{array}$ & Security \\
\hline 1 & $\begin{array}{l}\text { Apabila diminta untuk } \\
\text { menyebutkan Anti- } \\
\text { Virus, apa merek } \\
\text { pertama kali yang } \\
\text { muncul dalam benak } \\
\text { saya }\end{array}$ & $43,8 \%$ & $59,4 \%$ \\
\hline 2 & $\begin{array}{l}\text { Anti-Virus yang lebih } \\
\text { familiar }\end{array}$ & $43,8 \%$ & $62,5 \%$ \\
\hline 3 & $\begin{array}{l}\text { Saya mengingat salah } \\
\text { satu iklan Anti- }\end{array}$ & $46,9 \%$ & $59,4 \%$ \\
& Virus di Internet & & \\
\hline 4 & $\begin{array}{l}\text { Anti-Virus yang } \\
\text { menjadi alternatif } \\
\text { pilihan saat memilih } \\
\text { Anti-Virus }\end{array}$ & $46,9 \%$ & $59,4 \%$ \\
\hline
\end{tabular}

Tabel 2. Hasil Presentase Persepsi Kualitas (Perceived Quality)

\begin{tabular}{clcc}
\hline No. & Pernyataan / Pertanyaan & \multicolumn{2}{c}{ Presentase } \\
\cline { 3 - 4 } & & $\begin{array}{c}360 \\
\text { Securiry }\end{array}$ & $\begin{array}{c}\text { CM } \\
\text { Security }\end{array}$ \\
\hline 1 & $\begin{array}{l}\text { Anti-Virus yang } \\
\text { berkualitas }\end{array}$ & $37,5 \%$ & $65,5 \%$ \\
\hline 2 & $\begin{array}{l}\text { Anti-Virus yang mudah } \\
\text { dipakai }\end{array}$ & $40,6 \%$ & $62,5 \%$ \\
\hline 3 & $\begin{array}{l}\text { Anti-Virus yang cocok } \\
\text { untuk berbagai } \\
\text { kalangan/smartphone }\end{array}$ & $40,6 \%$ & $62,5 \%$ \\
\hline 4 & $\begin{array}{l}\text { Anti-Virus yang } \\
\text { memiliki banyak } \\
\text { kegunaan }\end{array}$ & $34,4 \%$ & $68,8 \%$ \\
\hline
\end{tabular}

Tabel 3. Hasil Presentase Asosiasi Merek (Brand Association)

\begin{tabular}{clcc}
\hline No. & \multicolumn{1}{c}{$\begin{array}{c}\text { Pernyataan } / \\
\text { Pertanyaan }\end{array}$} & \multicolumn{2}{c}{ Presentase } \\
\cline { 3 - 4 } & \multicolumn{1}{c}{$\begin{array}{c}360 \\
\text { Securiry }\end{array}$} & CM Security \\
\hline 1 & $\begin{array}{l}\text { Anti-Virus dengan } \\
\text { keamanan yang tinggi }\end{array}$ & $46,9 \%$ & $62,5 \%$ \\
\hline 2 & $\begin{array}{l}\text { Anti-Virus yang lebih } \\
\text { terkenal }\end{array}$ & $43,8 \%$ & $59,4 \%$ \\
\hline 3 & $\begin{array}{l}\text { Anti-Virus yang } \\
\text { diproduksi oleh } \\
\text { perusahaan yang } \\
\text { kredibilitasnya tinggi } \\
\text { (terpercaya) }\end{array}$ & $40,6 \%$ & $62,5 \%$ \\
\hline 4 & $\begin{array}{l}\text { Anti-Virus yang mudah } \\
\text { ditemui }\end{array}$ & $46,9 \%$ & $56,3 \%$ \\
\hline
\end{tabular}

Hasil yang didapatkan diatas telah menunjukan secara kesadaran antivirus responden telah memiliki kesadaran yang baik dan cukup disenangi banyak responden. Responden masih melihat bahwa CM security lebih baik dari anti virus 360 security. Dari sisi presepsi kualitas, antivirus telah cukup memenuhi kualitas keamanan yang baik walaupun masih belum signifikan. Responden masih melihat bahwa CM security lebih baik dari anti virus 360 security dalam hal kualitas. Pada sisi presentasi asosiasi merk, pengguna masih melihat Responden masih melihat bahwa CM security lebih baik dari anti virus 360 security. Hal ini dosebabkan kemudahan, beberapa fungsi pada antivirus dapat berfungsi sesuai tujuannya tetapi masih terdapat beberapa fungsi tertentu belum digunakan pengguna sesuai dengan peruntukannya sehingga masih belum cukup berguna. Sedangkan tingkat kepuasan, pengguna secara mayoritas telah menyatakan puas terhadap antivirus berbasis sehingga dapat terus digunakan dengan baik dan kedepannya diharapkan untuk terus digunakan. Pengguna masih tetap memilih anti virus CM security.

\section{KESIMPULAN}

Hasil penelitian ini dapat menyimpulkan bahwa sistem antivirus yang paling banyak digunakan adalah CM Security. Publik banyak menggunakan CM Security karena dilihat dari beberapa alasan yang menguntukngkan pengguna seperti mudah digunakan. Hasil dari studi ini dapat digunakan sebagai alat perbandingan atau sebagai bahan acuan untuk publik sebelum memilih produk. Penelitian ini dapat memberi saran untuk dilakukan: Ketika ingin memilih produk maka kita sebaiknya melihat kembali apa produk antivirus kita dapat melihat dari segi kecepatan untuk melalukan scan, keamanan yang ditawarkan, dan ukuran yang kita perlukan, seperti memilih antivirusnya

\section{REFERENSI}


[1] “Teknik Sampling," 2003. [Online]. Avaliable:http://library.usu.ac.id/download/ fk m/fkm-rozaini.pdf [Diakses pada Mei 2018]

[2] "Teknik Sampling," 2007. [Online]. Avaliable: http://www.fk.uii.ac.id/ upload/ klinik/elearning/ikm/tekniksampling penelitian-ikm-fkuii-naj.pdf [Diakses pada Mei 2018]

[3] "Rancang Bangun Sistem Tracer Study Alumni Unsrit Berbasis Web," 2017. [Online].Avaliable:

https://johnreimon.files.wordpress.com/

2018/04/sistem-tracer-studyalumni unsritberbasis-web.pdf [Diakses pada Mei 2018]

[4] "Analisis Perbandingan Produk Merek Global Dan Merek Lokal Terkait Bauran Pemasaran Dan Pengaruhnya Terhadap Keputusan Pembelian,” 2016. [Online]. Avaliable: http://administrasibisnis.student journal.ub.ac.id/index.php/jab/article/d ownload/1458/1837 [Diakses pada Mei 2018]

[5] Besar Sampel dan Teknik Sampling,". [Online].Avaliable:

http://gamel.fk.ugm.ac.id/pluginfile.php/50 645/mod_resource/content/1/Materi_11_Be sar_Sampel_dan_T eknik_Sampling.pdf

[6] "Simple Random Sampling,"2008. [Online]. Avaliable: $\quad$ http://www.ph.ucla.edu/epi/ rapidsu rveys/RScourse/RSbook_ch3.pdf

[7] "Simple Random Sampling Systematic Sampling Lecture 2,". [Online]. Avaliable: http://ocw.jhsph.edu/courses/statm ethodsforsamplesurveys/PDFs/Lect ure2.pdf

[8] "Simple Random Sampling,". [Online]. Avaliable: $\quad$ http://www.econ.upf.edu/ $\sim$ montalv o/cursos/technical_sampling.pdf

[9] “Simple Random Sampling,"2012. [Online]. Avaliable: http://dept.stat.lsa.umich.edu/ $\sim$ mou lib/sampling.pdf

[10] "Random Sampling,". [Online]. Avaliable: https://www.amsi.org.au/ESA_Seni or_Years/PDF/RandomSampling4b.pdf

[11] J. R. Batmetan Suyoto, J. D. C. L. Suares, "An Empirical Investigation on Customer Behavior to Adopt Mobile Commerce among the Y Generation in Indonesia", Sriwijaya International Conference On Engineering, Science \& Technology [SICEST 2016], 2016
[12] J.R. Batmetan, "Algoritma Ant Colony Optimization (ACO) untuk Pemilihan Jalur Tercepat Evakuasi Bencana Gunung Lokon Sulawesi Utara", Jurnal Teknologi Informasi-AITI, 2016, vol.13, no.2, pp 3148

[13] L. Madeso, D. R. Kabo, J. R. Batmetan, " Rancang Bangun Sistem Pakar Penentuan Status Gizi Pada Balita Menggunakan Metode Forward Chainning", E-Jurnal UNSRIT, vol.2

[14] J. R. Batmetan, V. R. Palilingan, " Higher Education Students' Behaviour to Adopt Mobile Learning", IOP Conference Series: Materials Science and Engineering, 2018, vol. 306, Issue 1, pp. 012110 (2018)

[15] V. R. Palilingan, J. R. Batmetan, " Incident Management in Academic Information System using ITIL Framework", IOP Conference Series: Materials Science and Engineering, 2018, vol. 306, Issue 1, pp. 012110 (2018)

[16] J. R. Batmetan, A. J. Santoso, Pranowo, " A Multiple-Objective Ant Colony Algorithm for Optimizing Disaster Relief Logistics", Advanced Science Letters, 2017, vol.23, no.3, pp. 2344-2347

[17] M. L. Tompodung, F. Supit, J. R. Batmetan, " Rancang Bangun Aplikasi Sensus Penduduk Berbasis Android", Buletin Sariputra, 2017, vol.7, pp. 57-61

[18] J. R. Batmetan, " Optimasi Strategi Smart Environment Dalam Mitigasi Bencana Menggunakan Multi-Objective Aco (MoAco) Algorithm", Pasca Sarjana Magister Teknik Informatika Universitas Atma Jaya Yogyakarta, 2016 